\title{
Cancer, Oxidative Stress, and Metastasis
}

\author{
Jennifer G. Gill, ${ }^{1,2}$ Elena Piskounova, ${ }^{2}$ and Sean J. Morrison ${ }^{2,3}$ \\ ${ }^{1}$ Department of Dermatology, University of Texas Southwestern Medical Center, Dallas, Texas 75390 \\ ${ }^{2}$ Department of Pediatrics, Children's Research Institute, University of Texas Southwestern \\ Medical Center, Dallas, Texas 75390 \\ ${ }^{3}$ Howard Hughes Medical Institute, University of Texas Southwestern Medical Center, \\ Dallas, Texas 75390 \\ Correspondence: Sean.Morrison@UTSouthwestern.edu
}

\begin{abstract}
Reactive oxygen species (ROS) are highly reactive molecules that arise from a number of cellular sources, including oxidative metabolism in mitochondria. At low levels they can be advantageous to cells, activating signaling pathways that promote proliferation or survival. At higher levels, ROS can damage or kill cells by oxidizing proteins, lipids, and nucleic acids. It was hypothesized that antioxidants might benefit high-risk patients by reducing the rate of ROS-induced mutations and delaying cancer initiation. However, dietary supplementation with antioxidants has generally proven ineffective or detrimental in clinical trials. High ROS levels limit cancer cell survival during certain windows of cancer initiation and progression. During these periods, dietary supplementation with antioxidants may promote cancer cell survival and cancer progression. This raises the possibility that rather than treating cancer patients with antioxidants, they should be treated with pro-oxidants that exacerbate oxidative stress or block metabolic adaptations that confer oxidative stress resistance.
\end{abstract}

Reactive oxygen species (ROS), including superoxide radicals $\left(\mathrm{O}_{2} \cdot{ }^{-}\right)$, hydroxyl radicals $(\mathrm{OH} \bullet)$, and hydrogen peroxide $\left(\mathrm{H}_{2} \mathrm{O}_{2}\right)$, are generated as by-products of aerobic metabolism as well as from a number of other sources. These ROS display varying reactivities toward different targets but share the ability to damage cells by oxidizing proteins, lipids, and DNA (Martinez-Cayuela 1995). The ability of ROS to mutate DNA and to damage cells raised the possibility that cellular aging and cancer initiation reflect accumulated ROS damage over time (Harman 1956). Although damage from ROS does contribute to aging and cancer initiation, ROS damage does not seem to provide a general explanation for the morbidities of aging, and antioxidant administration has so far failed to increase longevity outside of certain mutant genetic backgrounds (Finkel and Holbrook 2000). Nonetheless, decades of work in this area gave rise to the idea that antioxidants from the diet or from dietary supplements might slow aging and reduce cancer incidence by neutralizing cellular ROS (Greenwald et al. 1990). Results from clinical trials generally have not supported this idea.

\section{SOURCES AND EFFECTS OF ROS}

ROS are produced in various subcellular compartments by nonenzymatic and enzymatic reactions (HernandezGarcia et al. 2010). Nonenzymatic mechanisms include single-electron reduction of $\mathrm{O}_{2}$ to produce superoxide in the mitochondria. Enzymatic mechanisms are numerous and include NADPH oxidases, nitric oxide synthases, xanthine oxidase, cytochrome P450 enzymes, cyclooxygenases, and lipoxygenases (Gorrini et al. 2013b). The endoplasmic reticulum also serves as a source of ROS during protein folding via protein disulfide isomerase, endoplasmic reticulum oxidoreductin, NADPH oxidase (especially NOX4), and other mechanisms (Malhotra et al. 2008; Bhandary et al. 2012; Higa and Chevet 2012). Peroxisomes produce ROS through $\beta$-oxidation of fatty acids and flavin oxidase activity (Schrader and Fahimi 2006). Hypoxia, sustained mitochondrial respiration, ER stress, and oncogenes all contribute to high ROS levels in some cancer cells (Szatrowski and Nathan 1991; Gorrini et al. 2013b). Because ROS are so highly reactive, ROS generally oxidize targets within, or adjacent to, the intracellular compartment in which they are generated.

Cellular ROS levels can also increase as a result of UV irradiation, ionizing radiation, toxins such as heavy metals, chemotherapy, and neighboring inflammatory cells, although the mechanisms vary widely (Federico et al. 2007; Azzam et al. 2012; Vera-Ramirez et al. 2012). For example, the chemotherapeutic doxorubicin forms a complex with topoisomerase and DNA that leads to double-strand breaks, increasing ROS levels and potentiating cellular damage (Lyu et al. 2007; Rowe et al. 2008; Zhang et al. 2012). Doxorubicin also promotes mitochondrial dysfunction through multiple mechanisms including changes in iron metabolism and releasing electrons from the electron transport chain (Granados-Principal et al. 2010).

(C) 2016 Gill et al. This article is distributed under the terms of the Creative Commons Attribution-NonCommercial License, which permits reuse and redistribution, except for commercial purposes, provided that the original author and source are credited. 
At lower levels, ROS activate signaling that can be advantageous for cells, promoting proliferation, survival, or oxidative stress resistance (Ranjan et al. 2006; Rhee 2006; Schieber and Chandel 2014). Redox-sensitive signaling pathways include the PI3-kinase and MAP kinase signaling pathways in which ROS regulates signaling by epidermal growth factor (EGF) (Bae et al. 1997), Ras (Lander et al. 1997), platelet-derived growth factor (PDGF) (Sundaresan et al. 1995), and phosphatase and tensin homolog (PTEN) (Lee et al. 2002; Leslie et al. 2003). These pathways can be indirectly regulated by ROS or directly activated by "redox switches." For example, nitric oxide production results in S-nitrosylation of p $21^{\text {Ras }}$ at Cys118, increasing guanine nucleotide exchange and Ras signaling (Lander et al. 1997).

\section{ANTIOXIDANT MECHANISMS FOR ROS DEFENSE}

Cells must maintain homeostasis by limiting ROS production and having antioxidant mechanisms to neutralize ROS or mitigate oxidative stress. Antioxidant enzymes include superoxide dismutases (SODs), catalase, peroxiredoxins (PRDXs), thioredoxins, glutathione peroxidase, and heme oxygenase (Sabharwal and Schumacker 2014). Some of these enzymes, such as SOD, have different isoforms in mitochondria and in the cytoplasm. These enzymes work together to neutralize ROS (Fig. 1). For example, SOD can convert $\mathrm{O}_{2} \cdot{ }^{-}$to $\mathrm{O}_{2}$ or $\mathrm{H}_{2} \mathrm{O}_{2}$. Catalase and glutathione peroxidase subsequently convert the $\mathrm{H}_{2} \mathrm{O}_{2}$ to $\mathrm{H}_{2} \mathrm{O}$ and $\mathrm{O}_{2}$. Nonenzymatic antioxidants include proteins and metabolites produced by cells, such as thioredoxin, glutathione, and nicotinamide adenine dinucleotide phosphate (NADPH), as well as dietary components, such as vitamins $\mathrm{A}, \mathrm{C}$, and $\mathrm{E}$, selenium, and $\beta$-carotene. Thioredoxin and glutathione are abundant endogenous redox buffers that serve as electron donors to peroxidases, which convert $\mathrm{H}_{2} \mathrm{O}_{2}$ to $\mathrm{H}_{2} \mathrm{O}$ (Fig. 1). They can then be regenerated from their oxidized, disulfide forms, using NADPH as an electron donor.

Nuclear factor-erythroid 2-related factor 2 (NRF2) is a transcriptional master regulator of cellular redox status. It promotes the transcription of genes that encode antioxidant and detoxification enzymes in response to redox stress (Hayes and McMahon 2009). NRF2 is negatively regulated by Kelch-like ECH-associated protein 1 (KEAP1), which sequesters NRF2 in the cytoplasm (Hayes and Dinkova-Kostova 2014). However, ROS can oxidize and inactivate KEAP1, allowing NRF2 levels to increase in the nucleus and triggering the transcription of genes with antioxidant response elements in their promoters (Rushmore et al. 1991; Nioi et al. 2003). These genes include key components of the endogenous antioxidant response systems that import cystine into cells (Lewerenz et al. 2013) and promote the synthesis of glutathione (Higgins et al. 2009) and thioredoxin (Hayes and Dinkova-Kostova 2014). NRF2 also promotes the expression of glutathione peroxidase, glutathione reductase, and thioredoxin reductase (Fig. 1; Hayes and McMahon 2009; Abbas et al. 2011; Jeong et al. 2012; Hawkes et al. 2014; Lu and Holmgren 2014), as well as proteins such as ferritin, which blocks the formation of free radicals, and NADPH:quinone oxidoreductase 1, which inhibits the

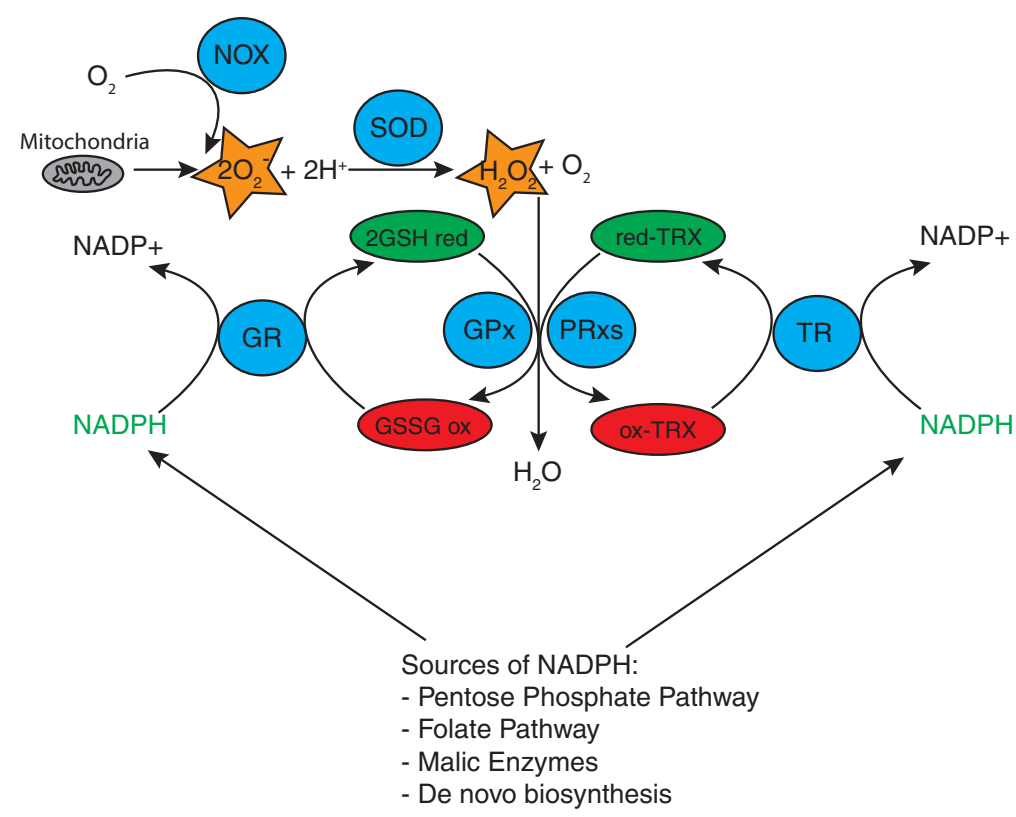

Figure 1. Endogenous antioxidant mechanisms. Reactive oxygen species (ROS) such as superoxide can be produced either in the cytoplasm or in mitochondria. Two main arms of the antioxidant response are shown: thioredoxin (TRX) and glutathione (GSH). Enzymes are highlighted in blue. GR, glutathione reductase; GSH red, reduced glutathione; GSSG ox, oxidized glutathione; GPx, glutathione peroxidase; SOD, superoxide dismutase; PRxs, peroxiredoxins; red-TRX, reduced thioredoxin; ox-TRX, oxidized thioredoxin; NOX, NADPH oxidase; NADPH, nicotinamide adenine dinucleotide phosphate. 
formation of free radicals by quinones (Nioi and Hayes 2004). Finally, NRF2 promotes the expression of NADPH-generating enzymes to produce the NADPH required for glutathione and thioredoxin regeneration (Thimmulappa et al. 2002; Lee et al. 2003; Wu et al. 2011; Mitsuishi et al. 2012; Singh et al. 2013). This concerted upregulation of approximately 200 genes enables the adaptation of cells to increased ROS levels (Hayes and Dinkova-Kostova 2014).

Tumor suppressors also help to control ROS. For example, BRCA1 and fumarate hydratase both promote NRF2 function through different mechanisms (Gorrini et al. 2013b). p53 decreases ROS levels by inhibiting glycolysis and promoting the generation of NADPH via the pentose phosphate pathway (Green and Chipuk 2006). The increased DNA damage in the absence of p53 can be partially rescued by treatment with the antioxidant $N$ acetylcysteine (NAC), suggesting that the effects of p53 on redox homeostasis are a significant component of its functions that promote genomic stability (Liu et al. 2004; Sablina et al. 2005).

\section{CLINICAL TRIALS OF ANTIOXIDANTS IN CANCER PREVENTION}

Based on the hypothesis that cellular damage from ROS is a major driver of aging and oncogenic mutations, dietary supplementation with antioxidants was proposed to prevent and/or treat cancer (Greenwald et al. 1990). The Nutritional Prevention of Cancer Study Group tested whether dietary supplementation with selenium (a component of glutathione peroxidase and thioredoxin reductase) could reduce the incidence of skin cancers in patients with a history of basal and/or squamous cell carcinomas (Clark et al. 1996). Although selenium did not protect participants from the development of additional skin cancers, selenium supplementation was associated with a nearly $40 \%$ reduction in total cancer incidence, particularly in prostate cancer. The Linxian General Population Nutrition Intervention Trial found that a combination of selenium, vitamin $\mathrm{E}$, and $\beta$-carotene reduced overall mortality as well as cancer rates (Blot et al. 1993; Qiao et al. 2009).

These promising findings spawned many additional trials to assess the efficacy of antioxidant use for cancer prevention (see Table 1 for a summary of randomized, placebo-controlled trials with more than 10,000 participants). Subsequent trials not only failed to reproduce these findings (Hennekens et al. 1996; Lee et al. 1999, 2005; Hercberg et al. 2004, 2007; Gaziano et al. 2009, 2012) but suggested that in some cases, antioxidants may actually promote cancer initiation and progression. The Alpha-Tocopherol Beta Carotene (ATBC) Cancer Prevention Study treated male smokers with vitamin $\mathrm{E}, \beta-$ carotene, both, or neither for 5-8 yr (ATBC 1994). Patients receiving $\beta$-carotene had an $18 \%$ increase in lung cancer incidence. These results were recapitulated in the CARET trial, which also found an increase in lung cancer incidence and mortality in participants taking $\beta$-carotene and vitamin A (Omenn et al. 1996a,b).
The SELECT trial was a randomized, double-blind, placebo-controlled trial of older males given vitamin $\mathrm{E}$, selenium, both, or neither for 7-12 yr (Lippman et al. 2009; Klein et al. 2011). Men taking vitamin E alone were significantly more likely to develop prostate cancer, though overall cancer incidence did not significantly differ between groups. Among patients who received selenium, those with high baseline selenium levels had an increased risk of high-grade prostate carcinoma whereas those with low baseline selenium did not (Kristal et al. 2014).

Some trials also tested the ability of antioxidants to prevent the formation of new primary tumors in patients who had already been treated for cancer. The EUROSCAN trial treated patients with a history of head and neck cancer or lung cancer for $2 \mathrm{yr}$ with vitamin A (retinyl palmitate), NAC, both, or neither (van Zandwijk et al. 2000). Patients receiving neither vitamin A nor NAC had the lowest incidence of new primary tumors, although this was not statistically significant. A Phase III randomized, double-blind, placebo-controlled trial tested the effect of selenium versus placebo for patients with resected non-small cell lung cancer (Karp et al. 2013). The trial was stopped early as selenium treatment was associated with a trend toward increased second primary tumors.

The U.S. Preventative Services Task Force (USPSTF) reviewed many of the above trials and concluded that there was insufficient data for or against the use of most nutrient supplements for cancer prevention (Moyer and U.S. Preventive Services Task Force 2014). Two exceptions included vitamin $\mathrm{E}$ and $\beta$-carotene. Vitamin $\mathrm{E}$ consistently showed no impact on cancer prevention. $\beta$-carotene showed an increased risk for lung cancer in smokers.

The other important question is whether dietary supplementation with antioxidants benefits healthy people. Many clinical trials have explored whether antioxidant use affects mortality due to heart disease, aging, or diseases of aging. A meta-analysis examining all-cause mortality in 68 randomized trials of antioxidants for many different indications included 232,606 participants and found a significant increase in mortality in patients taking $\beta$-carotene, vitamin $\mathrm{A}$, and vitamin $\mathrm{E}$ (Bjelakovic et al. 2007). An additional meta-analysis showed that antioxidant supplements significantly increased the risk of bladder cancer (Myung et al. 2010).

\section{CLINICAL TRIALS OF ANTIOXIDANTS IN CANCER TREATMENT}

In addition to cancer prevention, some trials have included antioxidants as adjuvant therapy in the treatment of patients with cancer. A systematic review found no benefit of supplemental ascorbate (vitamin C) for overall or progression-free survival in cancer patients, most of whom had breast or colorectal cancer (Jacobs et al. 2015). Another systematic review examined treatment efficacy and patient survival with the use of any adjuvant antioxidants during chemotherapy or radiotherapy (Yasueda et al. 2016). The trials showed contradictory results, but 
GILL ET AL.

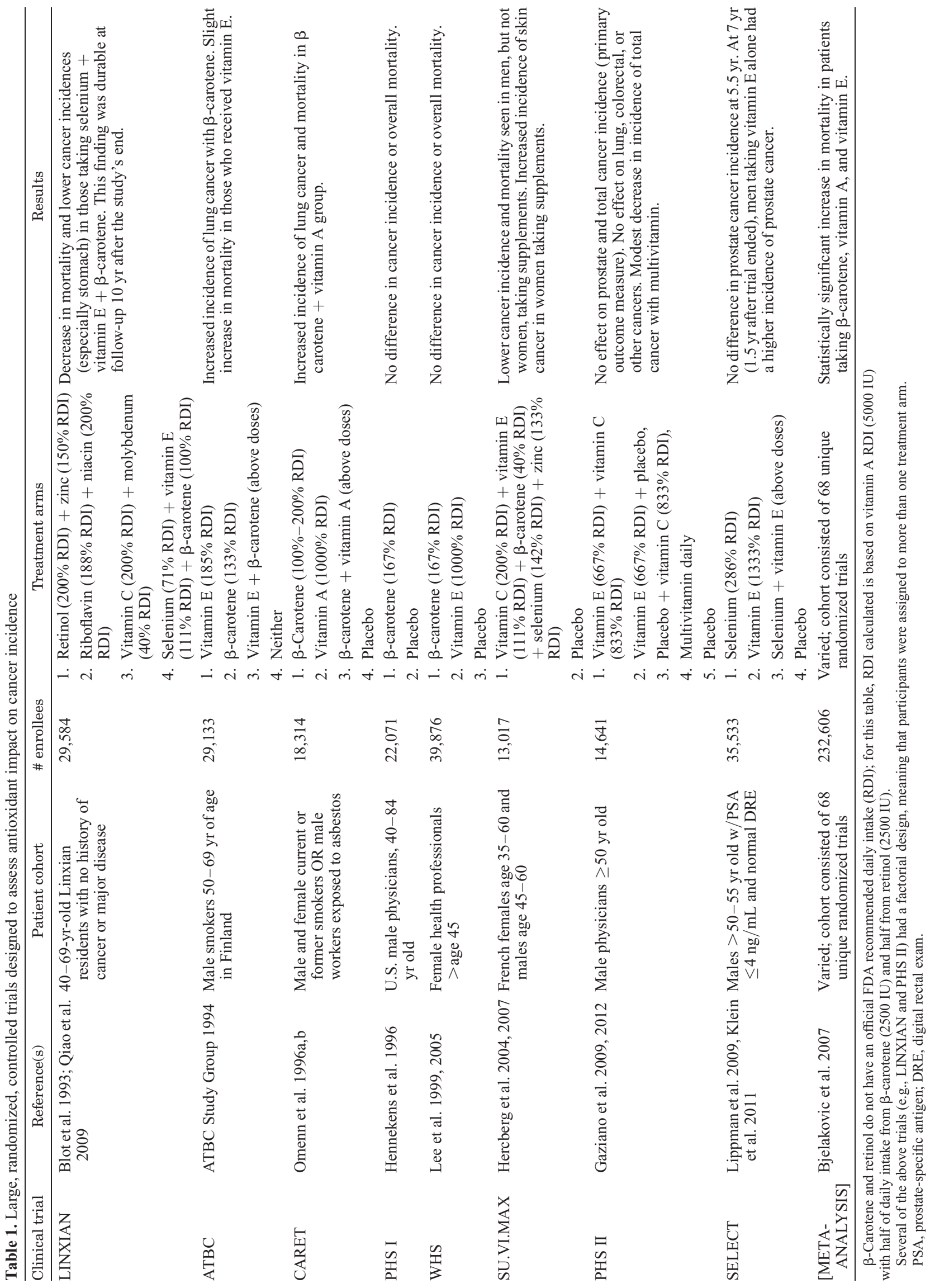


one trial showed that use of vitamin $E$ and $\beta$-carotene in head and neck cancer patients receiving radiotherapy increased the risk of recurrence $(\mathrm{RR}=2.41,95 \% \mathrm{CI}$ : $1.25-4.64)$ and cancer mortality $(\mathrm{RR}=3.38,95 \% \mathrm{CI}$ : $1.11-10.34$ ) specifically in smokers (Meyer et al. 2008).

Despite strong designs and very large numbers of participants, the above clinical trials (and other smaller trials) failed to yield clear evidence that antioxidants could reduce cancer development or progression. Contrary to what was expected, antioxidant use often appeared to increase cancer incidence, particularly in individuals at high risk.

\section{ROS IN CANCER INITIATION AND PROGRESSION}

ROS is a mutagen that promotes tumor initiation. ROS can oxidize guanine in DNA and RNA to form 8-hydroxyguanine (8-OHG) (Floyd 1990). 8-OHG can pair with adenine during DNA replication, resulting in $\mathrm{G}$ to $\mathrm{T}$ and $\mathrm{C}$ to A substitutions, potentially introducing missense mutations (Cheng et al. 1992). A large body of work has found a strong correlation between the formation of 8-OHG and carcinogenesis (Feig et al. 1994).

Consistent with the idea that ROS is carcinogenic, antioxidant enzymes are tumor suppressors. SOD is a family of three enzymes that are major scavengers of superoxide in the cytoplasm (SOD1), mitochondria (SOD2), and extracellularly (SOD3). Sod1-deficient mice develop liver cancer marked by extensive oxidative and DNA damage (Elchuri et al. 2005). Mice heterozygous for a null allele of Sod2 also form tumors, particularly lymphoma and pituitary adenoma (Van Remmen et al. 2003). Sod3-deficient mice do not form tumors, but SOD3 overexpression reduces tumor formation by $50 \%$ in a skin carcinogenesis model (Kim et al. 2005). Peroxiredoxin1 ( $\operatorname{Prd} \mathrm{x} 1$ )-deficient mice develop lymphomas, sarcomas, and carcinomas (Neumann et al. 2003).

Some other tumor suppressors also act partly by suppressing ROS generation. Loss-of-function mutations in multiple tumor suppressors that promote genomic integrity, including ataxia telangiectasia mutated (ATM), P53, and BRCA1, lead to the generation of ROS (Bae et al. 2004; Reliene et al. 2004; Sablina et al. 2005; Reliene and Schiestl 2006; Esteve et al. 2010; Gorrini et al. 2013a). This may reflect the leakage of damaged DNA into the cytoplasm in these cells, inducing an interferon-mediated innate immune response (as would be stimulated by viral DNA) that promotes the generation of ROS (Santos et al. 2014; Tasdogan et al. 2016; A Tasdogan and H Fehling, pers. comm.). Atm-deficient cells show genomic instability, oxidative stress, hematopoietic stem cell depletion, and lymphoid neoplasia (Reliene et al. 2004; Reliene and Schiestl 2006). Treatment of Atm-deficient mice with NAC largely rescues these phenotypes, reducing ROS levels, DNA damage, and cancer incidence (Ito et al. 2004). NAC treatment of p53-deficient mice has similar effects (Sablina et al. 2005). Although clinical trials in patients at high risk of cancer tended to show that antioxidants were often ineffective or deleterious for cancer risk, these results in mice raise the possibility that antioxidants might reduce cancer risk in certain sensitized genetic backgrounds.

Numerous studies have also demonstrated a link between oncogene signaling and oxidative stress, though the mechanisms by which oncogenes increase ROS levels are murky. Ras activation increases the generation of superoxide (Irani et al. 1997). BCR-ABL-transformed cells show increased intracellular ROS, as well as oxidative DNA damage and chromosomal fragmentation (Sattler et al. 2000; Nowicki et al. 2004). c-Myc overexpression increases ROS levels, DNA damage, and genomic instability (Felsher and Bishop 1999; Vafa et al. 2002). The increase in ROS levels as a result of oncogene signaling may contribute to ongoing mutagenesis and genomic instability in cancer cells, promoting cancer progression. To balance these potentially toxic effects of ROS, several oncogenes also promote the expression of NRF2, which reduces ROS levels and promotes tumorigenesis (DeNicola et al. 2011).

Consistent with the idea that ROS can promote cancer initiation by promoting mutagenesis but impair cancer progression by causing oxidative damage, antioxidant enzymes have bimodal effects on cancer initiation and progression. Prdx6 overexpression in keratinocytes can reduce the initiation of skin tumors, but once they arise, cancer progression is accelerated by $\operatorname{Prdx} 6$ overexpression (Rolfs et al. 2013). Similarly, NRF2 confers resistance to chemical carcinogens but also promotes cancer progression by protecting cancer cells from oxidative stress and DNA damage (Ramos-Gomez et al. 2001; Iida et al. 2004; Hayes and McMahon 2006; Hu et al. 2006; Xu et al. 2006; Ma 2013; Satoh et al. 2013). Increased NRF2 expression in human cancers correlates with a poor prognosis (Moon and Giaccia 2015). Deletion of NRF2 in pancreatic cancer cells increases DNA damage and decreases tumorigenesis (DeNicola et al. 2011). High levels of ROS are thus detrimental to cancer cells and cancer progression depends on endogenous antioxidants that attenuate oxidative stress.

\section{ROS AND METASTASIS}

Metastasis is a multistep process involving invasion, migration, intravasation into the blood, survival in circulation, extravasation into distant organs, and proliferation (Vanharanta and Massague 2013). Circulating cancer cells are commonly observed in the blood of patients and mice with various cancers (Nagrath et al. 2007; Stott et al. 2010; Yu et al. 2013, 2014; Sullivan et al. 2014). Nevertheless, metastasis is a very inefficient process (Vanharanta and Massague 2013) as very few metastasizing cancer cells survive and even fewer proliferate to form micrometastases (Luzzi et al. 1998; Cameron et al. 2000; Kienast et al. 2010). Accumulating evidence suggests that oxidative stress kills cancer cells at multiple stages of the metastatic process, contributing to the inefficiency of the process. 
Metastasis begins with detachment from the local extracellular matrix. Epithelial cells undergo cell death when they detach from extracellular matrix in culture as a result of reduced glucose uptake, ATP depletion, and oxidative stress (Debnath et al. 2002; Debnath and Brugge 2005). Oncogenic signaling promotes the survival of detached breast epithelial cells by increasing glucose uptake and flux through the pentose phosphate pathway, which generates NADPH and regenerates glutathione (Schafer et al. 2009). Multiple transcription factors also cooperate to induce an antioxidant response that promotes survival, including NRF2 and ATF4. NRF2 and ATF4 promote the expression of serine/glycine biosynthesis enzymes to increase glutathione synthesis (DeNicola et al. 2015) as well as heme oxygenase 1 (Dey et al. 2015), each of which reduces oxidative stress, blocks anoikis, and promotes survival during metastasis.

Cancer cells are more sensitive than normal cells to elevated ROS levels (Raj et al. 2011). Cancer cells rely on glutathione and thioredoxin to protect them from ROS during cancer initiation and cancer progression (Harris et al. 2015). Combined inhibition of glutathione and thioredoxin synergistically induces the death of cancer cells (Harris et al. 2015). Antioxidant treatment of mouse models of lung cancer increases tumor progression and reduces mouse survival by reducing ROS levels, DNA damage, and p53 expression in the cancer cells (Sayin et al. 2014). Oxidative stress also impairs cancer progression by globally suppressing protein translation: NRF2-deficient cancer cells show an increase in oxidized cysteine residues in components of the translational initiation complex, globally reducing translation (Chio et al. 2016). This phenotype can be rescued by antioxidant treatment. Consistent with the critical role of NRF2 in redox regulation, some cancers suppress ROS by mutations in KEAP1 or NRF2 that prevent NRF2 from being sequestered in the cytoplasm, constitutively activating NRF2 (Singh et al. 2006; Ohta et al. 2008; Shibata et al. 2008a,b).

Circulating melanoma cells in the blood of xenografted mice as well as metastatic nodules have higher levels of ROS relative to primary subcutaneous tumors (Piskounova et al. 2015). Oxidative stress is a barrier to distant metastasis in these melanomas as treatment with the antioxidant NAC increases the frequency of circulating melanoma cells in the blood, as well as metastatic disease burden, without significantly affecting the growth of primary subcutaneous tumors (Piskounova et al. 2015). The finding that distant metastasis is limited by oxidative stress is not an artifact of xenotransplantation into immunocompromised mice as similar results were observed in immunocompetent mice with autochthanous melanomas: Treatment with NAC or vitamin E promoted distant metastasis without affecting the growth of subcutaneous tumors (Le Gal et al. 2015). Consistent with this, cancer cells depend on NRF2 (Wang et al. 2016), thioredoxinlike 2 (Qu et al. 2011), superoxide dismutase (Kamarajugadda et al. 2013; Glasauer et al. 2014), and glutamate cysteine ligase (the rate-limiting step of glutathione synthesis) (Nguyen et al. 2016) to survive during metastasis.
A number of studies have thus indicated that reducing oxidative stress is critical for metastasis. Nonetheless, other studies have reported that ROS can promote metastasis. Antioxidants inhibit the metastasis of some cell lines (Ferraro et al. 2006; Ishikawa et al. 2008; Porporato et al. 2014). Mouse melanoma cells in an aged microenvironment show decreased APE1 expression as a result of changes in Wnt signaling, which increases ROS, metastasis, and therapy resistance (Kaur et al. 2016). Mouse lung carcinoma cells containing mitochondrial DNA with mutations in NADH dehydrogenase subunit 6 (ND6) displayed higher ROS levels and increased metastasis when compared with wild-type mitochondrial DNA and the increase in metastasis could be inhibited by NAC treatment (Ishikawa et al. 2008). ROS can also act cell-extrinsically in the tumor microenvironment to promote cancer progression (Jezierska-Drutel et al. 2013), either by influencing the properties of tumor stromal cells (Cat et al. 2006; Toullec et al. 2010) or by attenuating the activity of inflammatory cells (Satoh et al. 2010). These studies are a reminder that ROS can induce signaling that provides a selective advantage to cells in certain circumstances and that the net effect of ROS on cancer reflects a complex combination of adaptive and maladaptive consequences within the cells and their environment.

\section{CANCER CELLS UNDERGO METABOLIC CHANGES TO MANAGE ROS}

Because oxidative stress limits cancer progression, the rare cancer cells that successfully metastasize may undergo metabolic changes that allow them to cope with oxidative stress. Consistent with this, melanoma cells undergo reversible metabolic changes during metastasis that increase their fitness to form tumors after metastasis (Piskounova et al. 2015).

NADPH is central to oxidative stress resistance. In cells in which glutathione and thioredoxin have been depleted by oxidative stress, NADPH must be diverted to regenerate the reduced forms of these redox buffers (Fig. 2). Cancer cells use multiple metabolic pathways to generate NADPH, including the pentose phosphate (Patra and Hay 2014), folate (Fan et al. 2014), and malic enzyme pathways (Fig. 2). The pentose phosphate pathway is the first line of defense against oxidative stress in many human cells and can promote the survival of cells during neoplastic transformation and during detachment from extracellular matrix (Boada et al. 2000; Debnath et al. 2002; Debnath and Brugge 2005; Bensaad et al. 2006; Sukhatme and Chan 2012; Hu et al. 2013; Kuehne et al. 2015).

De novo serine synthesis and the folate pathway are another major source of NADPH for cancer cells (Fan et al. 2014; Lewis et al. 2014; Ye et al. 2014). De novo serine synthesis can be limiting for flux through the folate pathway, and reduced serine hydroxymethyltransferase expression reduces the cellular $\mathrm{NADPH} / \mathrm{NADP}^{+}$ratio while increasing ROS levels and cell death (Ye et al. 2014). Phosphoglycerate dehydrogenase (PHGDH) catalyzes the first step in serine biosynthesis. This enzyme is 
A Pentose Phosphate Pathway
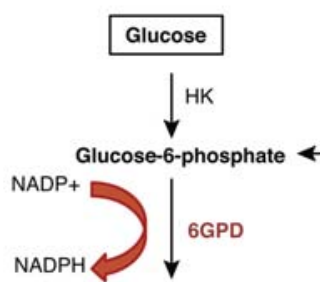

6-phosphogluconolactone

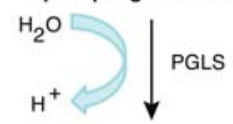

6-phosphogluconate

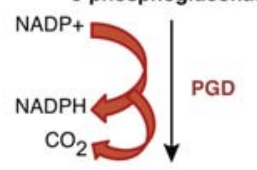

Ribulose-5-phosphate

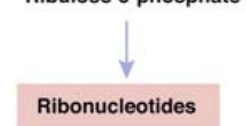

\section{Glycolysis}

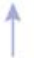

Glyceraldehyde-3-phosphate

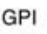

$\longleftrightarrow$ Fructose-6-phosphate
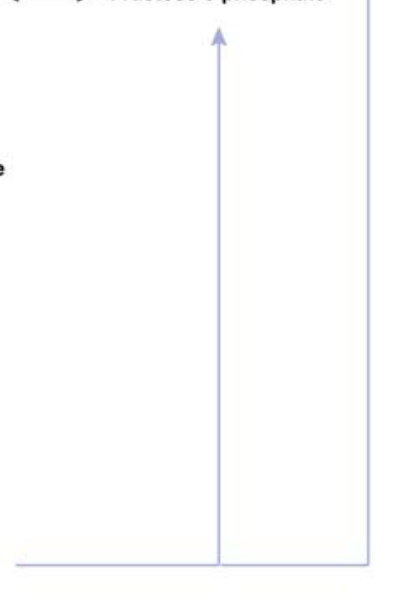

B Malic Enzymes

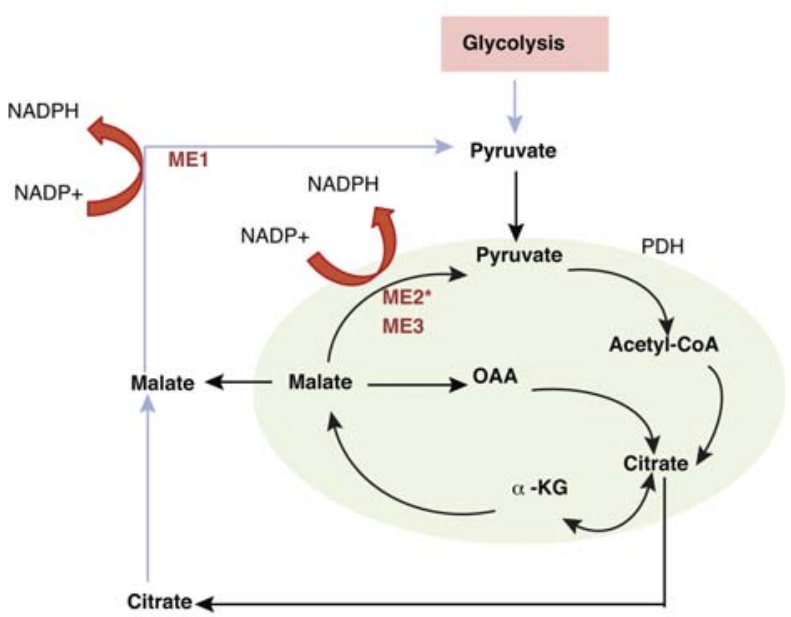

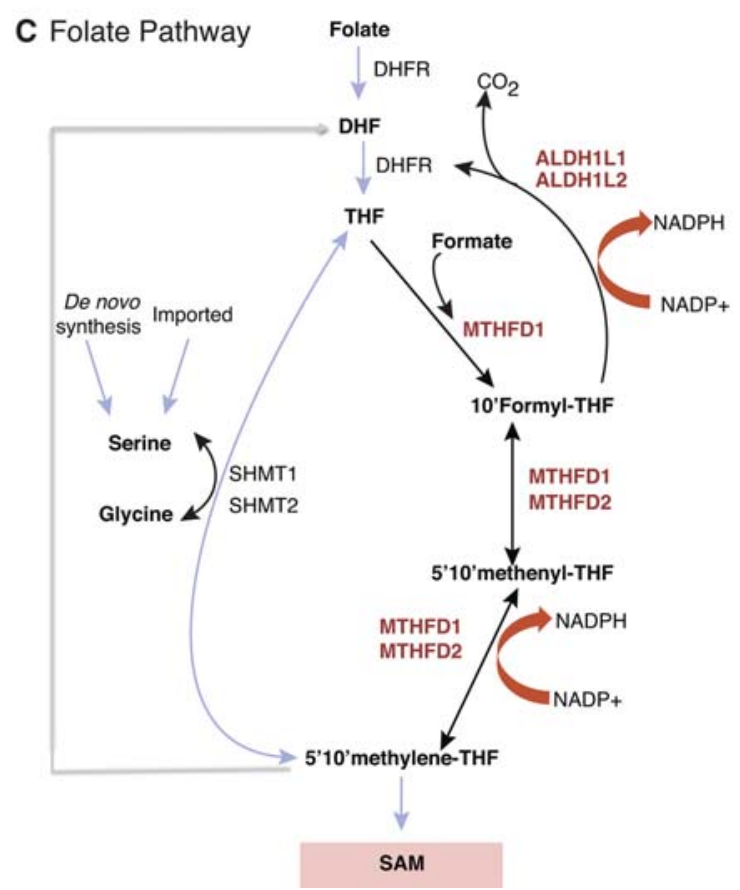

Figure 2. NADPH regenerating pathways. Cancer cells depend on different metabolic pathways to produce NADPH to regenerate endogenous antioxidants, such as GSH and TXN. $(A)$ The pentose phosphate pathway. In the pentose phosphate pathway, NADPH is generated in two reactions catalyzed by glucose-6-phosphate dehydrogenase (G6PD) and 6-phosphogluconate dehydrogenase (PGD), shown in red. G6PD catalyzes the rate-limiting step in the oxidative branch of the pentose phosphate pathway. Its activity is regulated by the NADP + NADPH ratio, where NADPH is the negative regulator and NADP + is required for proper enzymatic function. $(B)$ Malic enzymes. Three malic enzymes have been identified in mammalian cells. They differ with respect to their localization in the cytosol (ME1) versus mitochondria (ME2, ME3) and with respect to their use of NADP (ME1, ME3) versus NAD or NADP (ME2*) as electron acceptors. Malic enzymes mediate the conversion of malate to pyruvate, accompanied by the production of NADPH. $(C)$ The folate pathway. The folate pathway uses one-carbon groups that come from serine to generate either nucleotides or NADPH. Serine can either be synthesized de novo by cells or imported. Several enzymes within the folate pathway, aldehyde dehydrogenase L1 (ALDH1L1) and 2 (ALDH1L2), and methylenetetrahydrofolate dehydrogenase 1 (MTHFD1) and 2 (MTHFD2) are able to regenerate NADPH. 
increased in expression in many breast cancers and melanomas, and is necessary for the proliferation of those cells (Locasale et al. 2011; Mullarky et al. 2011; Possemato et al. 2011). The folate pathway uses one-carbon groups from serine to generate either nucleotides or NADPH. Several enzymes within the folate pathway generate NADPH including methyltetrahydrofolate dehydrogenases 1 and 2 (MTHFD1 and MTHFD2) and aldehyde dehydrogenase-like 1 and 2 (ALDH1L1 and ALDH1L2) (Fig. 2; Fan et al. 2014). ALDH1L2 expression reversibly increases in melanoma cells during metastasis and knockdown of ALDH1L2 or MTHFD1 reduces the metastasis of patient-derived melanoma xenografts in vivo without affecting the growth of primary tumors in the same mice (Piskounova et al. 2015).

Finally, malic enzymes mediate the conversion of malate to pyruvate, accompanied by NADPH production (Fig. 2). Malic enzymes promote the growth of several cancers (Son et al. 2013; Ren et al. 2014). ME2 expression is associated with reduced ROS levels in melanoma cells and promotes cutaneous melanoma proliferation and invasion in culture (Jiang et al. 2013).

Cancer cells sometimes benefit from metabolic changes that preserve NADPH for the regeneration of glutathione and thioredoxin. AMP-activated protein kinase (AMPK) is activated in response to ROS as well as during energy stress and can promote the survival of cells partly through redox regulation (Schafer et al. 2009). AMPK inhibits acetyl-CoA carboxylases, inhibiting the consumption of NADPH by fatty acid synthesis and promoting the generation of NADPH by fatty acid oxidation (Jeon et al. 2012). High ROS levels in cancer cells also decrease oxidative phosphorylation by promoting glycolysis by stabilizing hypoxia-inducible factor-1 (HIF-1) (Chandel et al. 2000; Semenza 2011) or by oxidizing and inhibiting pyruvate kinase M2, diverting glucose into the pentose phosphate pathway (Anastasiou et al. 2011). These changes may reflect a broader need to shut down anabolic pathways that generate ROS or consume NADPH in cancer cells experiencing oxidative stress.

Consistent with these observations, some cancer cells undergo metabolic changes during invasion in vitro and metastasis in vivo that would be expected to reduce the generation of ROS (Chen et al. 2007; Lu et al. 2010; Qu et al. 2011; Kamarajugadda et al. 2012, 2013; Dong et al. 2013; Shi et al. 2014). For example, HIF-1 activity is transiently increased during metastasis due to high ROS levels (Montagner et al. 2012; Vanharanta et al. 2013; Zhao et al. 2014). HIF-1 activation metabolically reprograms metastasizing cells away from oxidative phosphorylation to glycolysis and lactic acid production, through increased expression of lactate dehydrogenase and pyruvate dehydrogenase. These metabolic changes reduce ROS levels and promote survival during metastasis.

The metabolic plasticity of cancer cells allows them to undergo dynamic changes in mitochondrial mass and mitochondrial function that facilitate their ability to cope with energy stress and oxidative stress (Senft and Ronai 2016; Vyas et al. 2016). Both glycolysis and oxidative phosphorylation can be used in cancer cells in comple- mentary strategies to enhance metabolic plasticity to overcome changes in the tumor environment or in energy demands (Jose et al. 2011). PGC-1 $\alpha$, which promotes mitochondrial biogenesis, is dynamically expressed by cancer cells. Although metastasizing cells can increase mitochondrial biogenesis and respiration by increasing PGC- $1 \alpha$ expression (LeBleu et al. 2014), PGC-1 $\alpha$ inhibits metastasis in other contexts (Luo et al. 2016). Because PGC- $1 \alpha$ would be expected to increase mitochondrial mass and the generation of ROS, the observation that PGC- $1 \alpha^{\text {low }}$ cells have more metastatic potential in some cancers (Luo et al. 2016) is consistent with the observation that oxidative stress limits distant metastasis (Piskounova et al. 2015). Cancer cells also dynamically control mitochondrial fusion and fission to regulate oxidative phosphorylation and ROS levels (Hagenbuchner et al. 2013) and to promote invasion (Zhao et al. 2013). The question of whether metastasizing cancer cells benefit from increased or decreased mitochondrial function may depend on the tissue of origin as mitochondrial DNA (mtDNA) copy numbers vary widely across tumor types (Reznik et al. 2016).

\section{CONCLUSION}

ROS promote cancer initiation by promoting mutagenesis and perhaps by activating signaling pathways that promote proliferation, survival, and stress resistance. However, ROS also limits cancer initiation and progression by causing oxidative stress that kills many cancer cells. For this reason, cancer cells depend on a variety of mechanisms to suppress ROS and to cope with oxidative stress. Antioxidants promote cancer initiation and progression in experimental mouse models as well as in clinical trials. Cancer may be more effectively treated with pro-oxidants that exacerbate the oxidative stress experienced by cancer cells or that prevent metabolic adaptations that confer oxidative stress resistance.

\section{ACKNOWLEDGMENTS}

S.J.M. is a Howard Hughes Medical Institute (HHMI) Investigator, the Mary McDermott Cook Chair in Pediatric Genetics, the Kathryn and Gene Bishop Distinguished Chair in Pediatric Research, the director of the Hamon Laboratory for Stem Cells and Cancer, and a Cancer Prevention and Research Institute of Texas Scholar. We thank Alpaslan Tasdogan and Kati Ahlqvist for discussion and critical comments. This work was supported by the Cancer Prevention and Research Institute of Texas and the National Institutes of Health (R37 AG024945 and R01 DK100848).

\section{REFERENCES}

Abbas K, Breton J, Planson AG, Bouton C, Bignon J, Seguin C, Riquier S, Toledano MB, Drapier JC. 2011. Nitric oxide activates an Nrf2/sulfiredoxin antioxidant pathway in macrophages. Free Radic Biol Med 51: 107-114. 
Anastasiou D, Poulogiannis G, Asara JM, Boxer MB, Jiang JK, Shen M, Bellinger G, Sasaki AT, Locasale JW, Auld DS, et al. 2011. Inhibition of pyruvate kinase M2 by reactive oxygen species contributes to cellular antioxidant responses. Science 334: $1278-1283$.

ATBC. 1994. The effect of vitamin $E$ and $\beta$ carotene on the incidence of lung cancer and other cancers in male smokers. The Alpha-Tocopherol Beta Carotene Cancer Prevention Study Group. N Engl J Med 330: 1029-1035.

Azzam EI, Jay-Gerin JP, Pain D. 2012. Ionizing radiation-induced metabolic oxidative stress and prolonged cell injury. Cancer Lett 327: 48-60.

Bae YS, Kang SW, Seo MS, Baines IC, Tekle E, Chock PB, Rhee SG. 1997. Epidermal growth factor (EGF)-induced generation of hydrogen peroxide. Role in EGF receptor-mediated tyrosine phosphorylation. J Biol Chem 272: 217-221.

Bae I, Fan S, Meng Q, Rih JK, Kim HJ, Kang HJ, Xu J, Goldberg ID, Jaiswal AK, Rosen EM. 2004. BRCA1 induces antioxidant gene expression and resistance to oxidative stress. Cancer Res 64: 7893-7909.

Bensaad K, Tsuruta A, Selak MA, Vidal MN, Nakano K, Bartrons R, Gottlieb E, Vousden KH. 2006. TIGAR, a p53-inducible regulator of glycolysis and apoptosis. Cell 126: 107-120.

Bhandary B, Marahatta A, Kim HR, Chae HJ. 2012. An involvement of oxidative stress in endoplasmic reticulum stress and its associated diseases. Int $J$ Mol Sci 14: 434-456.

Bjelakovic G, Nikolova D, Gluud LL, Simonetti RG, Gluud C. 2007. Mortality in randomized trials of antioxidant supplements for primary and secondary prevention: Systematic review and meta-analysis. JAMA 297: 842-857.

Blot WJ, Li JY, Taylor PR, Guo W, Dawsey S, Wang GQ, Yang CS, Zheng SF, Gail M, Li GY, et al. 1993. Nutrition intervention trials in Linxian, China: Supplementation with specific vitamin/mineral combinations, cancer incidence, and disease-specific mortality in the general population. J Natl Cancer Inst 85: 1483-1492.

Boada J, Roig T, Perez X, Gamez A, Bartrons R, Cascante M, Bermudez J. 2000. Cells overexpressing fructose-2,6bisphosphatase showed enhanced pentose phosphate pathway flux and resistance to oxidative stress. FEBS Lett 480: 261-264.

Cameron MD, Schmidt EE, Kerkvliet N, Nadkarni KV, Morris VL, Groom AC, Chambers AF, MacDonald IC. 2000. Temporal progression of metastasis in lung: Cell survival, dormancy, and location dependence of metastatic inefficiency. Cancer Res 60: 2541-2546.

Cat B, Stuhlmann D, Steinbrenner H, Alili L, Holtkotter O, Sies H, Brenneisen P. 2006. Enhancement of tumor invasion depends on transdifferentiation of skin fibroblasts mediated by reactive oxygen species. J Cell Sci 119: 2727-2738.

Chandel NS, McClintock DS, Feliciano CE, Wood TM, Melendez JA, Rodriguez AM, Schumacker PT. 2000. Reactive oxygen species generated at mitochondrial complex III stabilize hypoxia-inducible factor-1 $\alpha$ during hypoxia: A mechanism of $\mathrm{O}_{2}$ sensing. $J$ Biol Chem 275: 25130-25138.

Chen EI, Hewel J, Krueger JS, Tiraby C, Weber MR, Kralli A, Becker K, Yates JR III, Felding-Habermann B. 2007. Adaptation of energy metabolism in breast cancer brain metastases. Cancer Res 67: 1472-1486.

Cheng KC, Cahill DS, Kasai H, Nishimura S, Loeb LA. 1992. 8Hydroxyguanine, an abundant form of oxidative DNA damage, causes $\mathrm{G} \rightarrow \mathrm{T}$ and $\mathrm{A} \rightarrow \mathrm{C}$ substitutions. J Biol Chem 267: $166-172$.

Chio II, Jafarnejad SM, Ponz-Sarvise M, Park Y, Rivera K, Palm W, Wilson J, Sangar V, Hao Y, Ohlund D, et al. 2016. NRF2 promotes tumor maintenance by modulating mRNA translation in pancreatic cancer. Cell 166: 963-976.

Clark LC, Combs GF Jr, Turnbull BW, Slate EH, Chalker DK, Chow J, Davis LS, Glover RA, Graham GF, Gross EG, et al. 1996. Effects of selenium supplementation for cancer prevention in patients with carcinoma of the skin. A randomized controlled trial. Nutritional Prevention of Cancer Study Group. JAMA 276: 1957-1963.
Debnath J, Brugge JS. 2005. Modelling glandular epithelial cancers in three-dimensional cultures. Nat Rev Cancer 5: $675-688$.

Debnath J, Mills KR, Collins NL, Reginato MJ, Muthuswamy SK, Brugge JS. 2002. The role of apoptosis in creating and maintaining luminal space within normal and oncogene-expressing mammary acini. Cell 111: 29-40.

DeNicola GM, Karreth FA, Humpton TJ, Gopinathan A, Wei C, Frese K, Mangal D, Yu KH, Yeo CJ, Calhoun ES, et al. 2011. Oncogene-induced Nrf2 transcription promotes ROS detoxification and tumorigenesis. Nature 475: 106-109.

DeNicola GM, Chen PH, Mullarky E, Sudderth JA, Hu Z, Wu D, Tang H, Xie Y, Asara JM, Huffman KE, et al. 2015. NRF2 regulates serine biosynthesis in non-small cell lung cancer. Nat Genet 47: 1475-1481.

Dey S, Sayers CM, Verginadis II, Lehman SL, Cheng Y, Cerniglia GJ, Tuttle SW, Feldman MD, Zhang PJ, Fuchs SY, et al. 2015. ATF4-dependent induction of heme oxygenase 1 prevents anoikis and promotes metastasis. J Clin Invest 125: 2592 2608.

Dong C, Yuan T, Wu Y, Wang Y, Fan TW, Miriyala S, Lin Y, Yao J, Shi J, Kang T, et al. 2013. Loss of FBP1 by Snailmediated repression provides metabolic advantages in basallike breast cancer. Cancer Cell 23: 316-331.

Elchuri S, Oberley TD, Qi W, Eisenstein RS, Jackson Roberts L, Van Remmen H, Epstein CJ, Huang TT. 2005. CuZnSOD deficiency leads to persistent and widespread oxidative damage and hepatocarcinogenesis later in life. Oncogene 24: $367-$ 380.

Esteve JM, Armengod ME, Knecht E. 2010. BRCA1 negatively regulates formation of autophagic vacuoles in MCF-7 breast cancer cells. Exp Cell Res 316: 2618-2629.

Fan J, Ye J, Kamphorst JJ, Shlomi T, Thompson CB, Rabinowitz JD. 2014. Quantitative flux analysis reveals folate-dependent NADPH production. Nature 510: 298-302.

Federico A, Morgillo F, Tuccillo C, Ciardiello F, Loguercio C. 2007. Chronic inflammation and oxidative stress in human carcinogenesis. Int J Cancer 121: 2381-2386.

Feig DI, Reid TM, Loeb LA. 1994. Reactive oxygen species in tumorigenesis. Cancer Res 54: 1890s-1894s.

Felsher DW, Bishop JM. 1999. Transient excess of MYC activity can elicit genomic instability and tumorigenesis. Proc Natl Acad Sci 96: 3940-3944.

Ferraro D, Corso S, Fasano E, Panieri E, Santangelo R, Borrello S, Giordano S, Pani G, Galeotti T. 2006. Pro-metastatic signaling by c-Met through RAC-1 and reactive oxygen species (ROS). Oncogene 25: 3689-3698.

Finkel T, Holbrook NJ. 2000. Oxidants, oxidative stress and the biology of ageing. Nature 408: 239-247.

Floyd RA. 1990. The role of 8-hydroxyguanine in carcinogenesis. Carcinogenesis 11: 1447-1450.

Gaziano JM, Glynn RJ, Christen WG, Kurth T, Belanger C, MacFadyen J, Bubes V, Manson JE, Sesso HD, Buring JE. 2009. Vitamins $E$ and $C$ in the prevention of prostate and total cancer in men: The Physicians' Health Study II randomized controlled trial. JAMA 301: 52-62.

Gaziano JM, Sesso HD, Christen WG, Bubes V, Smith JP, MacFadyen J, Schvartz M, Manson JE, Glynn RJ, Buring JE. 2012. Multivitamins in the prevention of cancer in men: The Physicians' Health Study II randomized controlled trial. JAMA 308: $1871-1880$.

Glasauer A, Sena LA, Diebold LP, Mazar AP, Chandel NS. 2014. Targeting SOD1 reduces experimental non-small-cell lung cancer. $J$ Clin Invest 124: 117-128.

Gorrini C, Baniasadi PS, Harris IS, Silvester J, Inoue S, Snow B, Joshi PA, Wakeham A, Molyneux SD, Martin B, et al. 2013a. BRCA1 interacts with Nrf2 to regulate antioxidant signaling and cell survival. $J$ Exp Med 210: 1529-1544.

Gorrini C, Harris IS, Mak TW. 2013b. Modulation of oxidative stress as an anticancer strategy. Nat Rev Drug Discov 12: 931-947.

Granados-Principal S, Quiles JL, Ramirez-Tortosa CL, SanchezRovira P, Ramirez-Tortosa MC. 2010. New advances in 
molecular mechanisms and the prevention of adriamycin toxicity by antioxidant nutrients. Food Chem Toxicol 48: $1425-$ 1438.

Green DR, Chipuk JE. 2006. p53 and metabolism: Inside the TIGAR. Cell 126: 30-32.

Greenwald P, Nixon DW, Malone WF, Kelloff GJ, Stern HR, Witkin KM. 1990. Concepts in cancer chemoprevention research. Cancer 65: 1483-1490.

Hagenbuchner J, Kuznetsov AV, Obexer P, Ausserlechner MJ. 2013. BIRC5/Survivin enhances aerobic glycolysis and drug resistance by altered regulation of the mitochondrial fusion/ fission machinery. Oncogene 32: 4748-4757.

Harman D. 1956. Aging: A theory based on free radical and radiation chemistry. J Gerontol 11: 298-300.

Harris IS, Treloar AE, Inoue S, Sasaki M, Gorrini C, Lee KC, Yung KY, Brenner D, Knobbe-Thomsen CB, Cox MA, et al. 2015. Glutathione and thioredoxin antioxidant pathways synergize to drive cancer initiation and progression. Cancer Cell 27: $211-222$.

Hawkes HJ, Karlenius TC, Tonissen KF. 2014. Regulation of the human thioredoxin gene promoter and its key substrates: A study of functional and putative regulatory elements. Biochim Biophys Acta 1840: 303-314.

Hayes JD, Dinkova-Kostova AT. 2014. The Nrf2 regulatory network provides an interface between redox and intermediary metabolism. Trends Biochem Sci 39: 199-218.

Hayes JD, McMahon M. 2006. The double-edged sword of Nrf2: Subversion of redox homeostasis during the evolution of cancer. Mol Cell 21: 732-734.

Hayes JD, McMahon M. 2009. NRF2 and KEAP1 mutations: Permanent activation of an adaptive response in cancer. Trends Biochem Sci 34: 176-188.

Hennekens CH, Buring JE, Manson JE, Stampfer M, Rosner B, Cook NR, Belanger C, LaMotte F, Gaziano JM, Ridker PM, et al. 1996. Lack of effect of long-term supplementation with $\beta$ carotene on the incidence of malignant neoplasms and cardiovascular disease. $N$ Engl $J$ Med 334: $1145-1149$.

Hercberg S, Galan P, Preziosi P, Bertrais S, Mennen L, Malvy D, Roussel AM, Favier A, Briancon S. 2004. The SU.VI.MAX Study: A randomized, placebo-controlled trial of the health effects of antioxidant vitamins and minerals. Arch Intern Med 164: $2335-2342$.

Hercberg S, Ezzedine K, Guinot C, Preziosi P, Galan P, Bertrais S, Estaquio C, Briancon S, Favier A, Latreille J, et al. 2007. Antioxidant supplementation increases the risk of skin cancers in women but not in men. J Nutr 137: 2098-2105.

Hernandez-Garcia D, Wood CD, Castro-Obregon S, Covarrubias L. 2010. Reactive oxygen species: A radical role in development? Free Radic Biol Med 49: 130-143.

Higa A, Chevet E. 2012. Redox signaling loops in the unfolded protein response. Cell Signal 24: 1548-1555.

Higgins LG, Kelleher MO, Eggleston IM, Itoh K, Yamamoto M, Hayes JD. 2009. Transcription factor Nrf2 mediates an adaptive response to sulforaphane that protects fibroblasts in vitro against the cytotoxic effects of electrophiles, peroxides and redox-cycling agents. Toxicol Appl Pharmacol 237: 267280.

Hu R, Xu C, Shen G, Jain MR, Khor TO, Gopalkrishnan A, Lin W, Reddy B, Chan JY, Kong AN. 2006. Gene expression profiles induced by cancer chemopreventive isothiocyanate sulforaphane in the liver of C57BL/6J mice and C57BL/ 6J/Nrf2 (-/ - ) mice. Cancer Lett 243: 170-192.

Hu T, Zhang C, Tang Q, Su Y, Li B, Chen L, Zhang Z, Cai T, Zhu Y. 2013. Variant G6PD levels promote tumor cell proliferation or apoptosis via the STAT3/5 pathway in the human melanoma xenograft mouse model. BMC Cancer 13: 251.

Iida K, Itoh K, Kumagai Y, Oyasu R, Hattori K, Kawai K, Shimazui T, Akaza H, Yamamoto M. 2004. Nrf2 is essential for the chemopreventive efficacy of oltipraz against urinary bladder carcinogenesis. Cancer Res 64: 6424-6431.

Irani K, Xia Y, Zweier JL, Sollott SJ, Der CJ, Fearon ER, Sundaresan M, Finkel T, Goldschmidt-Clermont PJ. 1997. Mito- genic signaling mediated by oxidants in Ras-transformed fibroblasts. Science 275: 1649-1652.

Ishikawa K, Takenaga K, Akimoto M, Koshikawa N, Yamaguchi A, Imanishi H, Nakada K, Honma Y, Hayashi J. 2008. ROS-generating mitochondrial DNA mutations can regulate tumor cell metastasis. Science 320: 661-664.

Ito K, Hirao A, Arai F, Matsuoka S, Takubo K, Hamaguchi I, Nomiyama K, Hosokawa K, Sakurada K, Nakagata N, et al. 2004. Regulation of oxidative stress by ATM is required for self-renewal of haematopoietic stem cells. Nature 431: 9971002.

Jacobs C, Hutton B, Ng T, Shorr R, Clemons M. 2015. Is there a role for oral or intravenous ascorbate (vitamin $\mathrm{C}$ ) in treating patients with cancer? A systematic review. Oncologist 20: 210-223.

Jeon SM, Chandel NS, Hay N. 2012. AMPK regulates NADPH homeostasis to promote tumour cell survival during energy stress. Nature 485: 661-665.

Jeong W, Bae SH, Toledano MB, Rhee SG. 2012. Role of sulfiredoxin as a regulator of peroxiredoxin function and regulation of its expression. Free Radic Biol Med 53: 447-456.

Jezierska-Drutel A, Rosenzweig SA, Neumann CA. 2013. Role of oxidative stress and the microenvironment in breast cancer development and progression. Adv Cancer Res 119: 107125.

Jiang P, Du W, Mancuso A, Wellen KE, Yang X. 2013. Reciprocal regulation of p53 and malic enzymes modulates metabolism and senescence. Nature 493: 689-693.

Jose C, Bellance N, Rossignol R. 2011. Choosing between glycolysis and oxidative phosphorylation: A tumor's dilemma? Biochim Biophys Acta 1807: 552-561.

Kamarajugadda S, Stemboroski L, Cai Q, Simpson NE, Nayak S, Tan M, Lu J. 2012. Glucose oxidation modulates anoikis and tumor metastasis. Mol Cell Biol 32: 1893-1907.

Kamarajugadda S, Cai Q, Chen H, Nayak S, Zhu J, He M, Jin Y, Zhang Y, Ai L, Martin SS, et al. 2013. Manganese superoxide dismutase promotes anoikis resistance and tumor metastasis. Cell Death Dis 4: e504.

Karp DD, Lee SJ, Keller SM, Wright GS, Aisner S, Belinsky SA, Johnson DH, Johnston MR, Goodman G, Clamon G, et al. 2013. Randomized, double-blind, placebo-controlled, phase III chemoprevention trial of selenium supplementation in patients with resected stage I non-small-cell lung cancer: ECOG 5597. J Clin Oncol 31: 4179-4187.

Kaur A, Webster MR, Marchbank K, Behera R, Ndoye A, Kugel CH III, Dang VM, Appleton J, O'Connell MP, Cheng $\mathrm{P}$, et al. 2016. sFRP2 in the aged microenvironment drives melanoma metastasis and therapy resistance. Nature 532: $250-254$.

Kienast Y, von Baumgarten L, Fuhrmann M, Klinkert WE, Goldbrunner R, Herms J, Winkler F. 2010. Real-time imaging reveals the single steps of brain metastasis formation. Nat Med 16: $116-122$.

Kim SH, Kim MO, Gao P, Youm CA, Park HR, Lee TS, Kim KS, Suh JG, Lee HT, Park BJ, et al. 2005. Overexpression of extracellular superoxide dismutase (EC-SOD) in mouse skin plays a protective role in DMBA/TPA-induced tumor formation. Oncol Res 15: 333-341.

Klein EA, Thompson IM Jr, Tangen CM, Crowley JJ, Lucia MS, Goodman PJ, Minasian LM, Ford LG, Parnes HL, Gaziano JM, et al. 2011. Vitamin E and the risk of prostate cancer: The Selenium and Vitamin E Cancer Prevention Trial (SELECT). JAMA 306: $1549-1556$.

Kristal AR, Darke AK, Morris JS, Tangen CM, Goodman PJ, Thompson IM, Meyskens FL Jr, Goodman GE, Minasian LM, Parnes HL, et al. 2014. Baseline selenium status and effects of selenium and vitamin E supplementation on prostate cancer risk. J Natl Cancer Inst 106: djt456.

Kuehne A, Emmert H, Soehle J, Winnefeld M, Fischer F, Wenck H, Gallinat S, Terstegen L, Lucius R, Hildebrand J, et al. 2015. Acute activation of oxidative pentose phosphate pathway as first-line response to oxidative stress in human skin cells. Mol Cell 59: 359-371. 
Lander HM, Hajjar DP, Hempstead BL, Mirza UA, Chait BT, Campbell S, Quilliam LA. 1997. A molecular redox switch on $\mathrm{p} 21^{\text {ras }}$. Structural basis for the nitric oxide-p21 ${ }^{\text {ras }}$ interaction. $J$ Biol Chem 272: 4323-4326.

LeBleu VS, O'Connell JT, Gonzalez Herrera KN, Wikman H, Pantel K, Haigis MC, de Carvalho FM, Damascena A, Domingos Chinen LT, Rocha RM, et al. 2014. PGC-1 $\alpha$ mediates mitochondrial biogenesis and oxidative phosphorylation in cancer cells to promote metastasis. Nat Cell Biol 16: $992-$ 1003, 1001-1015.

Lee IM, Cook NR, Manson JE, Buring JE, Hennekens CH. 1999. $\beta$-Carotene supplementation and incidence of cancer and cardiovascular disease: The Women's Health Study. J Natl Cancer Inst 91: 2102-2106.

Lee SR, Yang KS, Kwon J, Lee C, Jeong W, Rhee SG. 2002. Reversible inactivation of the tumor suppressor PTEN by $\mathrm{H}_{2} \mathrm{O}_{2}$. J Biol Chem 277: 20336-20342.

Lee JM, Calkins MJ, Chan K, Kan YW, Johnson JA. 2003. Identification of the NF-E2-related factor-2-dependent genes conferring protection against oxidative stress in primary cortical astrocytes using oligonucleotide microarray analysis. $J$ Biol Chem 278: 12029-12038.

Lee IM, Cook NR, Gaziano JM, Gordon D, Ridker PM, Manson JE, Hennekens CH, Buring JE. 2005. Vitamin E in the primary prevention of cardiovascular disease and cancer: The Women's Health Study: A randomized controlled trial. JAMA 294: 56-65.

Le Gal K, Ibrahim MX, Wiel C, Sayin VI, Akula MK, Karlsson C, Dalin MG, Akyurek LM, Lindahl P, Nilsson J, et al. 2015. Antioxidants can increase melanoma metastasis in mice. Sci Transl Med 7: 308re308.

Leslie NR, Bennett D, Lindsay YE, Stewart H, Gray A, Downes CP. 2003. Redox regulation of PI 3-kinase signalling via inactivation of PTEN. EMBO J 22: 5501-5510.

Lewerenz J, Hewett SJ, Huang Y, Lambros M, Gout PW, Kalivas PW, Massie A, Smolders I, Methner A, Pergande M, et al. 2013. The cystine/glutamate antiporter system $x_{c}^{-}$in health and disease: From molecular mechanisms to novel therapeutic opportunities. Antioxid Redox Signal 18: 522-555.

Lewis CA, Parker SJ, Fiske BP, McCloskey D, Gui DY, Green CR, Vokes NI, Feist AM, Vander Heiden MG, Metallo CM. 2014. Tracing compartmentalized NADPH metabolism in the cytosol and mitochondria of mammalian cells. Mol Cell 55: $253-263$.

Lippman SM, Klein EA, Goodman PJ, Lucia MS, Thompson IM, Ford LG, Parnes HL, Minasian LM, Gaziano JM, Hartline JA, et al. 2009. Effect of selenium and vitamin E on risk of prostate cancer and other cancers: The Selenium and Vitamin E Cancer Prevention Trial (SELECT). JAMA 301: 39-51.

Liu G, Parant JM, Lang G, Chau P, Chavez-Reyes A, El-Naggar AK, Multani A, Chang S, Lozano G. 2004. Chromosome stability, in the absence of apoptosis, is critical for suppression of tumorigenesis in Trp53 mutant mice. Nat Genet 36: $63-68$.

Locasale JW, Grassian AR, Melman T, Lyssiotis CA, Mattaini KR, Bass AJ, Heffron G, Metallo CM, Muranen T, Sharfi H, et al. 2011. Phosphoglycerate dehydrogenase diverts glycolytic flux and contributes to oncogenesis. Nat Genet 43: $869-$ 874.

Lu J, Holmgren A. 2014. The thioredoxin antioxidant system. Free Radic Biol Med 66: 75-87.

Lu X, Bennet B, Mu E, Rabinowitz J, Kang Y. 2010. Metabolomic changes accompanying transformation and acquisition of metastatic potential in a syngeneic mouse mammary tumor model. J Biol Chem 285: 9317-9321.

Luo C, Lim JH, Lee Y, Granter SR, Thomas A, Vazquez F, Widlund HR, Puigserver P. 2016. A PGC1 $\alpha$-mediated transcriptional axis suppresses melanoma metastasis. Nature 537: $422-426$.

Luzzi KJ, MacDonald IC, Schmidt EE, Kerkvliet N, Morris VL, Chambers AF, Groom AC. 1998. Multistep nature of metastatic inefficiency: Dormancy of solitary cells after successful extravasation and limited survival of early micrometastases. Am J Pathol 153: 865-873.

Lyu YL, Kerrigan JE, Lin CP, Azarova AM, Tsai YC, Ban Y, Liu LF. 2007. Topoisomerase II $\beta$ mediated DNA doublestrand breaks: Implications in doxorubicin cardiotoxicity and prevention by dexrazoxane. Cancer Res 67: 8839-8846.

Ma Q. 2013. Role of nrf2 in oxidative stress and toxicity. Annu Rev Pharmacol Toxicol 53: 401-426.

Malhotra JD, Miao H, Zhang K, Wolfson A, Pennathur S, Pipe SW, Kaufman RJ. 2008. Antioxidants reduce endoplasmic reticulum stress and improve protein secretion. Proc Natl Acad Sci 105: 18525-18530.

Martinez-Cayuela M. 1995. Oxygen free radicals and human disease. Biochimie 77: 147-161.

Meyer F, Bairati I, Fortin A, Gelinas M, Nabid A, Brochet F, Tetu B. 2008. Interaction between antioxidant vitamin supplementation and cigarette smoking during radiation therapy in relation to long-term effects on recurrence and mortality: A randomized trial among head and neck cancer patients. Int $J$ Cancer 122: 1679-1683.

Mitsuishi Y, Taguchi K, Kawatani Y, Shibata T, Nukiwa T, Aburatani H, Yamamoto M, Motohashi H. 2012. Nrf2 redirects glucose and glutamine into anabolic pathways in metabolic reprogramming. Cancer Cell 22: 66-79.

Montagner M, Enzo E, Forcato M, Zanconato F, Parenti A, Rampazzo E, Basso G, Leo G, Rosato A, Bicciato S, et al. 2012. SHARP1 suppresses breast cancer metastasis by promoting degradation of hypoxia-inducible factors. Nature 487: 380-384.

Moon EJ, Giaccia A. 2015. Dual roles of NRF2 in tumor prevention and progression: Possible implications in cancer treatment. Free Radic Biol Med 79: 292-299.

Moyer VA; U.S. Preventive Services Task Force. 2014. Vitamin, mineral, and multivitamin supplements for the primary prevention of cardiovascular disease and cancer: U.S. Preventive Services Task Force recommendation statement. Ann Intern Med 160: $558-564$

Mullarky E, Mattaini KR, Vander Heiden MG, Cantley LC, Locasale JW. 2011. PHGDH amplification and altered glucose metabolism in human melanoma. Pigment Cell Melanoma Res 24: 1112-1115.

Myung SK, Kim Y, Ju W, Choi HJ, Bae WK. 2010. Effects of antioxidant supplements on cancer prevention: Meta-analysis of randomized controlled trials. Ann Oncol 21: 166-179.

Nagrath S, Sequist LV, Maheswaran S, Bell DW, Irimia D, Ulkus L, Smith MR, Kwak EL, Digumarthy S, Muzikansky A, et al. 2007. Isolation of rare circulating tumour cells in cancer patients by microchip technology. Nature 450: 1235-1239.

Neumann CA, Krause DS, Carman CV, Das S, Dubey DP, Abraham JL, Bronson RT, Fujiwara Y, Orkin SH, Van Etten RA. 2003. Essential role for the peroxiredoxin Prdx1 in erythrocyte antioxidant defence and tumour suppression. Nature 424: $561-565$.

Nguyen A, Loo JM, Mital R, Weinberg EM, Man FY, Zeng Z, Paty PB, Saltz L, Janjigian YY, de Stanchina E, et al. 2016. PKLR promotes colorectal cancer liver colonization through induction of glutathione synthesis. J Clin Invest 126: 681694.

Nioi P, Hayes JD. 2004. Contribution of NAD(P)H:quinone oxidoreductase 1 to protection against carcinogenesis, and regulation of its gene by the Nrf2 basic-region leucine zipper and the arylhydrocarbon receptor basic helix-loop-helix transcription factors. Mutat Res 555: 149-171.

Nioi P, McMahon M, Itoh K, Yamamoto M, Hayes JD. 2003. Identification of a novel Nrf2-regulated antioxidant response element (ARE) in the mouse $\mathrm{NAD}(\mathrm{P}) \mathrm{H}$ :quinone oxidoreductase 1 gene: Reassessment of the ARE consensus sequence. Biochem J 374: 337-348.

Nowicki MO, Falinski R, Koptyra M, Slupianek A, Stoklosa T, Gloc E, Nieborowska-Skorska M, Blasiak J, Skorski T. 2004. $\mathrm{BCR} / \mathrm{ABL}$ oncogenic kinase promotes unfaithful repair of the reactive oxygen species-dependent DNA double-strand breaks. Blood 104: 3746-3753. 
Ohta T, Iijima K, Miyamoto M, Nakahara I, Tanaka H, Ohtsuji M, Suzuki T, Kobayashi A, Yokota J, Sakiyama T, et al. 2008. Loss of Keap1 function activates Nrf2 and provides advantages for lung cancer cell growth. Cancer Res 68: $1303-$ 1309.

Omenn GS, Goodman GE, Thornquist MD, Balmes J, Cullen MR, Glass A, Keogh JP, Meyskens FL Jr, Valanis B, Williams $\mathrm{JH}$ Jr, et al. 1996a. Risk factors for lung cancer and for intervention effects in CARET, the $\beta$-Carotene and Retinol Efficacy Trial. J Natl Cancer Inst 88: 1550-1559.

Omenn GS, Goodman GE, Thornquist MD, Balmes J, Cullen MR, Glass A, Keogh JP, Meyskens FL, Valanis B, Williams $\mathrm{JH}$, et al. 1996b. Effects of a combination of $\beta$ carotene and vitamin A on lung cancer and cardiovascular disease. $N$ Engl J Med 334: 1150-1155.

Patra KC, Hay N. 2014. The pentose phosphate pathway and cancer. Trends Biochem Sci 39: 347-354.

Piskounova E, Agathocleous M, Murphy MM, Hu Z, Huddlestun SE, Zhao Z, Leitch AM, Johnson TM, DeBerardinis RJ, Morrison SJ. 2015. Oxidative stress inhibits distant metastasis by human melanoma cells. Nature 527: 186-191.

Porporato PE, Payen VL, Perez-Escuredo J, De Saedeleer CJ, Danhier P, Copetti T, Dhup S, Tardy M, Vazeille T, Bouzin C, et al. 2014. A mitochondrial switch promotes tumor metastasis. Cell Rep 8: 754-766.

Possemato R, Marks KM, Shaul YD, Pacold ME, Kim D, Birsoy K, Sethumadhavan S, Woo HK, Jang HG, Jha AK, et al. 2011. Functional genomics reveal that the serine synthesis pathway is essential in breast cancer. Nature 476: 346-350.

Qiao YL, Dawsey SM, Kamangar F, Fan JH, Abnet CC, Sun XD, Johnson LL, Gail MH, Dong ZW, Yu B, et al. 2009. Total and cancer mortality after supplementation with vitamins and minerals: Follow-up of the Linxian General Population Nutrition Intervention Trial. J Natl Cancer Inst 101: 507-518.

Qu Y, Wang J, Ray PS, Guo H, Huang J, Shin-Sim M, Bukoye BA, Liu B, Lee AV, Lin X, et al. 2011. Thioredoxin-like 2 regulates human cancer cell growth and metastasis via redox homeostasis and NF-kB signaling. J Clin Invest 121: $212-$ 225.

Raj L, Ide T, Gurkar AU, Foley M, Schenone M, Li X, Tolliday NJ, Golub TR, Carr SA, Shamji AF, et al. 2011. Selective killing of cancer cells by a small molecule targeting the stress response to ROS. Nature 475: 231-234.

Ramos-Gomez M, Kwak MK, Dolan PM, Itoh K, Yamamoto M, Talalay P, Kensler TW. 2001. Sensitivity to carcinogenesis is increased and chemoprotective efficacy of enzyme inducers is lost in $n r f 2$ transcription factor-deficient mice. Proc Natl Acad Sci 98: 3410-3415.

Ranjan P, Anathy V, Burch PM, Weirather K, Lambeth JD, Heintz NH. 2006. Redox-dependent expression of cyclin D1 and cell proliferation by Nox 1 in mouse lung epithelial cells. Antioxid Redox Signal 8: 1447-1459.

Reliene R, Schiestl RH. 2006. Antioxidant $N$-acetyl cysteine reduces incidence and multiplicity of lymphoma in Atm deficient mice. DNA Repair (Amst) 5: 852-859.

Reliene R, Fischer E, Schiestl RH. 2004. Effect of $N$-acetyl cysteine on oxidative DNA damage and the frequency of DNA deletions in Atm-deficient mice. Cancer Res 64: 5148-5153.

Ren JG, Seth P, Clish CB, Lorkiewicz PK, Higashi RM, Lane AN, Fan TW, Sukhatme VP. 2014. Knockdown of malic enzyme 2 suppresses lung tumor growth, induces differentiation and impacts PI3K/AKT signaling. Sci Rep 4: 5414.

Reznik E, Miller ML, Senbabaoglu Y, Riaz N, Sarungbam J, Tickoo SK, Al-Ahmadie HA, Lee W, Seshan VE, Hakimi AA, et al. 2016. Mitochondrial DNA copy number variation across human cancers. Elife 5: e10769.

Rhee SG. 2006. Cell signaling. $\mathrm{H}_{2} \mathrm{O}_{2}$, a necessary evil for cell signaling. Science 312: 1882-1883.

Rolfs F, Huber M, Gruber F, Bohm F, Pfister HJ, Bochkov VN, Tschachler E, Dummer R, Hohl D, Schafer M, et al. 2013. Dual role of the antioxidant enzyme peroxiredoxin 6 in skin carcinogenesis. Cancer Res 73: 3460-3469.
Rowe LA, Degtyareva N, Doetsch PW. 2008. DNA damageinduced reactive oxygen species (ROS) stress response in Saccharomyces cerevisiae. Free Radic Biol Med 45: 11671177.

Rushmore TH, Morton MR, Pickett CB. 1991. The antioxidant responsive element. Activation by oxidative stress and identification of the DNA consensus sequence required for functional activity. J Biol Chem 266: 11632-11639.

Sabharwal SS, Schumacker PT. 2014. Mitochondrial ROS in cancer: Initiators, amplifiers or an Achilles' heel? Nat Rev Cancer 14: 709-721.

Sablina AA, Budanov AV, Ilyinskaya GV, Agapova LS, Kravchenko JE, Chumakov PM. 2005. The antioxidant function of the p53 tumor suppressor. Nat Med 11: 1306-1313.

Santos MA, Faryabi RB, Ergen AV, Day AM, Malhowski A, Canela A, Onozawa M, Lee JE, Callen E, Gutierrez-Martinez P, et al. 2014. DNA-damage-induced differentiation of leukaemic cells as an anti-cancer barrier. Nature 514: 107-111.

Satoh H, Moriguchi T, Taguchi K, Takai J, Maher JM, Suzuki T, Winnard PT Jr, Raman V, Ebina M, Nukiwa T, et al. 2010. Nrf2-deficiency creates a responsive microenvironment for metastasis to the lung. Carcinogenesis 31: 1833-1843.

Satoh H, Moriguchi T, Takai J, Ebina M, Yamamoto M. 2013. Nrf2 prevents initiation but accelerates progression through the Kras signaling pathway during lung carcinogenesis. Cancer Res 73: 4158-4168.

Sattler M, Verma S, Shrikhande G, Byrne CH, Pride YB, Winkler T, Greenfield EA, Salgia R, Griffin JD. 2000. The BCR/ $\mathrm{ABL}$ tyrosine kinase induces production of reactive oxygen species in hematopoietic cells. J Biol Chem 275: $24273-$ 24278.

Sayin VI, Ibrahim MX, Larsson E, Nilsson JA, Lindahl P, Bergo MO. 2014. Antioxidants accelerate lung cancer progression in mice. Sci Transl Med 6: $221 \mathrm{ra} 215$.

Schafer ZT, Grassian AR, Song L, Jiang Z, Gerhart-Hines Z, Irie HY, Gao S, Puigserver P, Brugge JS. 2009. Antioxidant and oncogene rescue of metabolic defects caused by loss of matrix attachment. Nature 461: 109-113.

Schieber M, Chandel NS. 2014. ROS function in redox signaling and oxidative stress. Curr Biol 24: R453-R462.

Schrader M, Fahimi HD. 2006. Peroxisomes and oxidative stress. Biochim Biophys Acta 1763: 1755-1766.

Semenza GL. 2011. Regulation of metabolism by hypoxia-inducible factor 1. Cold Spring Harb Symp Quant Biol 76: $347-$ 353.

Senft D, Ronai ZA. 2016. Regulators of mitochondrial dynamics in cancer. Curr Opin Cell Biol 39: 43-52.

Shi Z, Wang B, Chihanga T, Kennedy MA, Weber GF. 2014. Energy metabolism during anchorage-independence. Induction by osteopontin-c. PLOS ONE 9: e105675.

Shibata T, Kokubu A, Gotoh M, Ojima H, Ohta T, Yamamoto M, Hirohashi S. 2008a. Genetic alteration of Keap1 confers constitutive Nrf2 activation and resistance to chemotherapy in gallbladder cancer. Gastroenterology 135: 1358-1368, 1368 e $1351-1354$.

Shibata T, Ohta T, Tong KI, Kokubu A, Odogawa R, Tsuta K, Asamura H, Yamamoto M, Hirohashi S. 2008b. Cancer related mutations in NRF2 impair its recognition by Keap1-Cul3 E3 ligase and promote malignancy. Proc Natl Acad Sci 105: $13568-13573$.

Singh A, Misra V, Thimmulappa RK, Lee H, Ames S, Hoque MO, Herman JG, Baylin SB, Sidransky D, Gabrielson E, et al. 2006. Dysfunctional KEAP1-NRF2 interaction in non-smallcell lung cancer. PLoS Med 3: e420.

Singh A, Happel C, Manna SK, Acquaah-Mensah G, Carrerero J, Kumar S, Nasipuri P, Krausz KW, Wakabayashi N, Dewi R, et al. 2013. Transcription factor NRF2 regulates miR-1 and miR-206 to drive tumorigenesis. J Clin Invest 123: $2921-$ 2934.

Son J, Lyssiotis CA, Ying H, Wang X, Hua S, Ligorio M, Perera RM, Ferrone CR, Mullarky E, Shyh-Chang N, et al. 2013. Glutamine supports pancreatic cancer growth through a KRAS-regulated metabolic pathway. Nature 496: 101-105. 
Stott SL, Lee RJ, Nagrath S, Yu M, Miyamoto DT, Ulkus L, Inserra EJ, Ulman M, Springer S, Nakamura Z, et al. 2010. Isolation and characterization of circulating tumor cells from patients with localized and metastatic prostate cancer. Sci Transl Med 2: 25ra23.

Sukhatme VP, Chan B. 2012. Glycolytic cancer cells lacking 6phosphogluconate dehydrogenase metabolize glucose to induce senescence. FEBS Lett 586: 2389-2395.

Sullivan JP, Nahed BV, Madden MW, Oliveira SM, Springer S, Bhere D, Chi AS, Wakimoto H, Rothenberg SM, Sequist LV, et al. 2014. Brain tumor cells in circulation are enriched for mesenchymal gene expression. Cancer Discov 4: 12991309.

Sundaresan M, Yu ZX, Ferrans VJ, Irani K, Finkel T. 1995. Requirement for generation of $\mathrm{H}_{2} \mathrm{O}_{2}$ for platelet-derived growth factor signal transduction. Science 270: 296-299.

Szatrowski TP, Nathan CF. 1991. Production of large amounts of hydrogen peroxide by human tumor cells. Cancer Res 51: 794-798.

Tasdogan A, Kumar S, Allies G, Bausinger J, Beckel F, Hofemeister H, Mulaw M, Madan V, Scharfetter-Kochanek K, Feuring-Buske M, et al. 2016. DNA damage-induced HSPC malfunction depends on ROS accumulation downstream of IFN-1 signaling and bid mobilization. Cell Stem Cell 19: $752-767$.

Thimmulappa RK, Mai KH, Srisuma S, Kensler TW, Yamamoto M, Biswal S. 2002. Identification of Nrf2-regulated genes induced by the chemopreventive agent sulforaphane by oligonucleotide microarray. Cancer Res 62: 5196-5203.

Toullec A, Gerald D, Despouy G, Bourachot B, Cardon M, Lefort S, Richardson M, Rigaill G, Parrini MC, Lucchesi C, et al. 2010. Oxidative stress promotes myofibroblast differentiation and tumour spreading. EMBO Mol Med 2: 211-230.

Vafa O, Wade M, Kern S, Beeche M, Pandita TK, Hampton GM, Wahl GM. 2002. c-Myc can induce DNA damage, increase reactive oxygen species, and mitigate $\mathrm{p} 53$ function: A mechanism for oncogene-induced genetic instability. Mol Cell 9: $1031-1044$.

Vanharanta S, Massague J. 2013. Origins of metastatic traits. Cancer Cell 24: 410-421.

Vanharanta S, Shu W, Brenet F, Hakimi AA, Heguy A, Viale A, Reuter VE, Hsieh JJ, Scandura JM, Massague J. 2013. Epigenetic expansion of VHL-HIF signal output drives multiorgan metastasis in renal cancer. Nat Med 19: 50-56.

Van Remmen H, Ikeno Y, Hamilton M, Pahlavani M, Wolf N, Thorpe SR, Alderson NL, Baynes JW, Epstein CJ, Huang TT, et al. 2003. Life-long reduction in MnSOD activity results in increased DNA damage and higher incidence of cancer but does not accelerate aging. Physiol Genomics 16: 29-37.

van Zandwijk N, Dalesio O, Pastorino U, de Vries N, van Tinteren H. 2000. EUROSCAN, a randomized trial of vitamin A and $N$-acetylcysteine in patients with head and neck cancer or lung cancer. For the European Organization for Research and Treatment of Cancer Head and Neck and Lung Cancer Cooperative Groups. J Natl Cancer Inst 92: 977-986.

Vera-Ramirez L, Ramirez-Tortosa M, Perez-Lopez P, GranadosPrincipal S, Battino M, Quiles JL. 2012. Long-term effects of systemic cancer treatment on DNA oxidative damage: The potential for targeted therapies. Cancer Lett 327: 134-141.

Vyas S, Zaganjor E, Haigis MC. 2016. Mitochondria and cancer. Cell 166: 555-566.

Wang H, Liu X, Long M, Huang Y, Zhang L, Zhang R, Zheng Y, Liao X, Wang Y, Liao Q, et al. 2016. NRF2 activation by antioxidant antidiabetic agents accelerates tumor metastasis. Sci Transl Med 8: 334ra351.

Wu KC, Cui JY, Klaassen CD. 2011. Beneficial role of Nrf2 in regulating NADPH generation and consumption. Toxicol Sci 123: $590-600$

Xu C, Huang MT, Shen G, Yuan X, Lin W, Khor TO, Conney AH, Kong AN. 2006. Inhibition of 7,12-dimethylbenz(a)anthracene-induced skin tumorigenesis in C57BL/ 6 mice by sulforaphane is mediated by nuclear factor E2-related factor 2. Cancer Res 66: 8293-8296.

Yasueda A, Urushima H, Ito T. 2016. Efficacy and interaction of antioxidant supplements as adjuvant therapy in cancer treatment: A systematic review. Integr Cancer Ther 15: 1739 .

Ye J, Fan J, Venneti S, Wan YW, Pawel BR, Zhang J, Finley LW, $\mathrm{Lu} \mathrm{C}$, Lindsten T, Cross JR, et al. 2014. Serine catabolism regulates mitochondrial redox control during hypoxia. Cancer Discov 4: 1406-1417.

Yu M, Bardia A, Wittner BS, Stott SL, Smas ME, Ting DT, Isakoff SJ, Ciciliano JC, Wells MN, Shah AM, et al. 2013. Circulating breast tumor cells exhibit dynamic changes in epithelial and mesenchymal composition. Science 339: 580-584.

Yu M, Bardia A, Aceto N, Bersani F, Madden MW, Donaldson MC, Desai R, Zhu H, Comaills V, Zheng Z, et al. 2014. Cancer therapy. Ex vivo culture of circulating breast tumor cells for individualized testing of drug susceptibility. Science 345: $216-220$.

Zhang S, Liu X, Bawa-Khalfe T, Lu LS, Lyu YL, Liu LF, Yeh ET. 2012. Identification of the molecular basis of doxorubicin-induced cardiotoxicity. Nat Med 18: 1639-1642.

Zhao J, Zhang J, Yu M, Xie Y, Huang Y, Wolff DW, Abel PW, $\mathrm{Tu}$ Y. 2013. Mitochondrial dynamics regulates migration and invasion of breast cancer cells. Oncogene 32: 48144824.

Zhao T, Zhu Y, Morinibu A, Kobayashi M, Shinomiya K, Itasaka S, Yoshimura M, Guo G, Hiraoka M, Harada H. 2014. HIF-1-mediated metabolic reprogramming reduces ROS levels and facilitates the metastatic colonization of cancers in lungs. Sci Rep 4: 3793. 


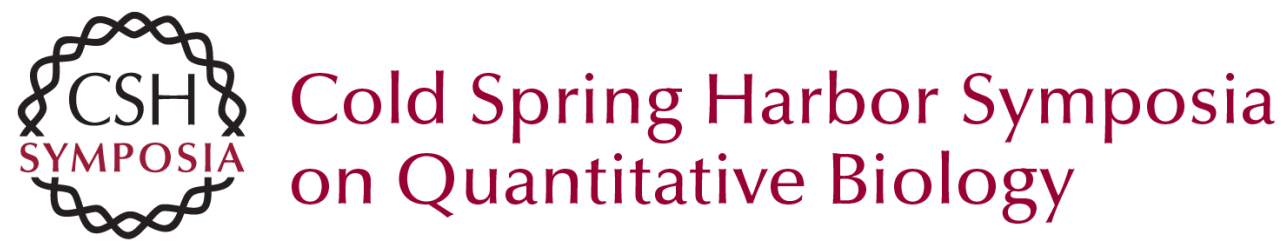

\section{Cancer, Oxidative Stress, and Metastasis}

Jennifer G. Gill, Elena Piskounova and Sean J. Morrison

Cold Spring Harb Symp Quant Biol 2016 81: 163-175 originally published online January 12, 2017

Access the most recent version at doi:10.1101/sqb.2016.81.030791

References This article cites 172 articles, 47 of which can be accessed free at: http://symposium.cshlp.org/content/81/163.full.html\#ref-list-1

Creative This article is distributed under the terms of the

Commons http://creativecommons.org/licenses/by-nc/4.0/, which permits reuse and License redistribution, except for commercial purposes, provided that the original author and source are credited.

Email Alerting Receive free email alerts when new articles cite this article - sign up in Service the box at the top right corner of the article or click here. 